\title{
Isolation and Identification of Microbial Species Found in Cocoa Fermentation as Microbial Starter Culture Candidates for Cocoa Bean Fermentation in Colombia
}

\author{
María Denis Lozano Tovar ${ }^{\left.{ }^{*}\right)}$, Geraldine Tibasosa ${ }^{2}$, Carlos Mario González ${ }^{1)}$, Karen Ballestas \\ Alvarez ${ }^{1)}$, Martha del Pilar López Hernández ${ }^{1)}$, and Fernando Rodriguez ${ }^{2)}$ \\ ${ }^{1)}$ Corporación Colombiana de Investigación Agropecuaria (AGROSAVIA), \\ Centro de Investigación Nataima, Km 9, Espinal-Ibague, Tolima, Colombia \\ ${ }^{2)}$ Corporación Colombiana de Investigación Agropecuaria (AGROSAVIA), \\ Centro de Investigación Tibaitatá, Km 14, vía Mosquera-Bogotá, Colombia. \\ ${ }^{3}$ Universidad Nacional de Colombia, Bogotá Campus - Facultad de Ciencias Agrarias - \\ Instituto de Ciencia y Tecnología de Alimentos (ICTA), Bogotá, Cundinamarca, Colombia \\ *Corresponding author: mlozano@agrosavia, mardeloz@hotmail.com. \\ Received: 23 April 2020 / Accepted: 15 October 2020
}

\begin{abstract}
Microbial activity involved in the cocoa beans fermentation process is essential to maintain and improve the organoleptic and nutritional qualities of chocolate; therefore, the aim of this investigation was to search and select microbial isolates with the potential to improve the quality of cocoa beans. Fermentation experiments were conducted on farms located in Maceo (Antioquia), San Vicente de Chucurí (Santander), and Rivera and Algeciras (Huila), Colombia. Yeast, lactic acid bacteria (LAB), acetic acid bacteria (AAB), and mesophilic aerobic microorganisms were obtained from different fermentation batches. The growth of these microorganisms was tested in six treatments as follows: $50 \%$ cocoa pulp agar (CPA), high concentrations of glucose $(10 \%)$, ethanol $(5 \%)$, and acetic acid $(7 \%)$, an acidic $\mathrm{pH}$ of 3.0 , and a high temperature of $50^{\circ} \mathrm{C}$ for $24 \mathrm{~h}$. The isolates with the highest growth were identified by $18 \mathrm{~S}$ and $16 \mathrm{~S}$ rRNA gene analysis, revealing a high diversity of species associated with cocoa fermentation, including eight species of yeasts (Debaryomyces hansenii, Meyerozyma guillermondii, Wickerhanomyces anomalus, Pichia guillermondii, Pichia kudriavzevii, Trichosporon asahii, Candida parapsilosis, and Pichia manshurica), six species of LAB (Pediococcus acidilactici, Lactobacillus brevis, Lactobacillus plantarum, Lactobacillus farraginis, Lactobacillus rhamnosus, and Leuconostoc mesenteroides), four species of AAB (Gluconobacter japonicus, Acetobacter tropicalis, Acetobacter pasteurianus, and Acetobacter malorum/tropicalis), and three species of Bacillus spp. (Bacillus aryabhattai /megaterium, Bacillus subtilis, and Bacillus coagulans). In general, microbial populations increased in cocoa batches after $12 \mathrm{~h}$ of fermentation and decreased after $84-96 \mathrm{~h}$. All the yeast isolates grew in $10 \%$ glucose and CPA, $85.7 \%$ in $5 \%$ ethanol, and $95 \%$ at a $\mathrm{pH}$ of 3.0. All the yeast isolates were affected by $7 \%$ acetic acid and incubation at $50^{\circ} \mathrm{C}$ for $24 \mathrm{~h}$. Eighty-five percent of the LAB grew in $10 \%$ glucose, $100 \%$ in $5 \%$ ethanol, $42.8 \%$ in CPA, $64 \%$ at a pH of 3.0 , and $35.7 \%$ grew after being exposed to $50^{\circ} \mathrm{C}$ for $24 \mathrm{~h}$; all were affected by $7 \%$ acetic acid. As for the AAB, $100 \%$ grew in $10 \%$ glucose, $71 \%$ in $7 \%$ ethanol, $100 \%$ grew in CPA, in $7 \%$ acetic acid, and at a pH of 3.0, while $100 \%$ were affected by incubation at $50^{\circ} \mathrm{C}$. Three yeast isolates, W. anomalus, D. hansenii and M. guillermondii, three LAB isolates, $P$. acidilactici, L. brevis, and L. plantarum, and three AAB isolates, A. tropicalis, A. pasteurianus and G. japonicus, were selected as promising strains to be used in a microbial starter culture for cocoa bean fermentation to improve the organoleptic quality of cocoa.
\end{abstract}

Keywords: Cocoa bean, fermentation, Theobroma, microorganisms 


\section{INTRODUCTION}

Cocoa fermentation is an important process for grain quality. In addition to the microbial population, other factors influence this process, such as environmental conditions, management practices, type of material, and environmental pollution (air, dust, and insects), which make fermentation outcome highly variable (De Vuyst \& Weckx, 2016). In the fermentation of grains, many microorganisms in growth and processing environments intervene (Schwan \& Wheals, 2004). Proper fermentation is directed by a particular succession of microbial activities, where four groups of microbes have been characterized, including yeasts, lactic acid bacteria (LAB), acetic acid bacteria (AAB) and some species of the Bacillus genus, which are synonymous of a good fermentation (De Vuyst \& Weckx, 2016; Lima et al., 2011). The cocoa pulp is composed mainly of water (82-87\%), sugars $(10-13 \%)$, pentosan $(2-3 \%)$, citric acid (1-2\%), and salts $(8-10 \%)$, which stimulate the growth of microorganisms populations (Schwan \& Wheals, 2004). During the first 48 hours, the fermentation conditions are low in oxygen, and the grains are colonized by yeasts and LAB that degrade the seed pulp; this, in turn, favors the entry of oxygen into the fermentation mass. Both yeasts and $\mathrm{LAB}$ consume pulp sugars and organic acids, producing ethanol and lactate. The increase in oxygen in the fermentation mass favors the colonization of $\mathrm{AAB}$. The oxidation of ethanol by AAB produces $\mathrm{CO}_{2}$ and heat, which increases the temperature of the mass that can reach a temperature of $51^{\circ} \mathrm{C}$ (Schwan \& Wheals, 2004).

The LAB contributes to the fermentation of cocoa, controlling bacterial growth and $\mathrm{pH}$, and, therefore, the desired metabolism conditions of microorganisms and beans (De Vuyst et al., 2010). Ethanol is oxidized to acetic acid by AAB. Besides, volatile sub- stances produced during fermentation, such as alcohols, aldehydes, esters, and ketones, contribute to the generation of essential flavor and aroma precursors in grains (Schwan \& Wheals, 2004; Lima et al., 2011; Ho et al., 2014).

Many studies have reported the diversity of microorganism species present in cocoa fermentation; however, it is crucial to identify the most beneficial strains for improving grain quality (Thompson et al., 2013). Due to the high microbial diversity, the use of molecular tools for the identification of interspecific and intraspecific diversity has increased significantly (Guerber et al., 2003). The analysis of the DNA of each cell provides the highest amount of information on the genotypic and phenotypic identities of each organism. The PCR technique using specific primers identifies and characterizes microorganisms. With the help of molecular markers for the identification of species and populations, the restrictive fragment analysis of PCR products has proven to be suitable for the study of different bacteria and yeast species by identifying them at the genus level.

Accordingly, the aim of this study was to improve the knowledge of the microbial population dynamics in cocoa fermentation on producer farms in different Colombian cocoa-producing regions and to identify isolates with potential characteristics for improving the quality of cocoa beans.

\section{MATERIALS AND METHODS}

\section{Monitoring and Isolation in Specific Culture Media}

\section{Isolation of microorganisms}

Cocoa fermentation was monitored in three municipalities on farms selected due 
to the good quality characteristics of their cocoa beans. Three hundred grams of beans were aseptically scooped from the center of the fermenting mass at $12 \mathrm{~h}$ intervals to isolate microorganisms. Forty grams of the cocoa beans were mixed with sterile saline solution $(0.85 \%$ sodium chloride (Merck $\mathrm{KGaA}$ ) at a rate of $1: 1.25$ using a vortex (IKA MS3 digital) for $10 \mathrm{~min}$ until obtaining a cocoa pulp solution. Serial 10 -fold dilutions were made until $10^{-14}$ in sterile saline solution followed by spread platting of $0.1 \mathrm{~mL}$ agar media specific to each class of organism for isolation and enumeration. Values of colony-forming units per milliliter $(\mathrm{CFU} / \mathrm{mL})$ were transformed to $\log 10 \mathrm{CFU} / \mathrm{mL}$. Specific media for each microbial class were employed as follows: Yeast [(Freitas, 1998), TYGKCC$0.5 \%$ casein peptone, $0.5 \%$ yeast extract, $0.1 \%$ D-glucose, $0.1 \% \mathrm{~K}_{2} \mathrm{HPO}_{4}, 0.1 \%$ $\mathrm{CaCO}_{3}, 1 \%$ cocoa pulp (Freitas, 1998), 500 $\mathrm{mg} / \mathrm{L}$ chloramphenicol, and $1.5 \%$ agar]; acetic acid bacteria [(Ohmori, 1982), 1\% yeast extract, $0.4 \%$ pectone, $6 \%$ glucose, $1 \%$ calcium carbonate, $2 \%$ agar, and $100 \mathrm{mg} /$ L nystatin, at $\mathrm{pH} 7.4]$; lactic acid bacteria [ $1 \%$ peptone, $0.5 \%$ yeast extract, $2 \% \mathrm{D}$-glucose, $0.5 \% \mathrm{~K}_{2} \mathrm{HPO}_{4}, 0.5 \% \mathrm{CH}_{3} \mathrm{COONa} .3 \mathrm{H}_{2} \mathrm{O}$, $0.05 \% \mathrm{MgSO}_{4} .7 \mathrm{H}_{2} \mathrm{O}, 0.02 \% \mathrm{MnSO}_{4} \cdot 4 \mathrm{H}_{2} \mathrm{O}$, $1 \mathrm{~mL}$ Tween $80,1.8 \%$ agar, and $10 \%$ tomato juice (Ardhana \& Fleet, 2003). Cycloheximide was replaced by nystatin $(3,000 \mathrm{IU}$ that correspond to $1 \mathrm{mg}$ of nystatin), at $\mathrm{pH}$ 6.5]. All media were autoclaved at $121^{\circ} \mathrm{C}$ for $15 \mathrm{~min}$. Incubations were performed at $30^{\circ} \mathrm{C}$ from 48 to $72 \mathrm{~h}$ (Lefeber et al., 2012), and the numbers of $\log 10 \mathrm{CFU} / \mathrm{mL}$ in each culture medium were recorded.

\section{Physicochemical characteristics of the cocoa beans during fermentation}

To determine the $\mathrm{pH}$ of the beans and testas, $4 \mathrm{~g}$ of beans were weighed, and the testas were removed with a scalpel. The testas and beans were placed into separate mortars, each containing $20 \mathrm{~mL}$ of distilled water, macerated, and then the $\mathrm{pH}$ was measured in each. The titratable acidity was determined with $0.1 \mathrm{~N} \mathrm{NaOH}$ (López et al., 2019). The rest of the sample was subjected to drying by solar radiation until reaching a constant weight. Dried samples were stored at $1 \pm 2{ }^{\circ} \mathrm{C}$. The fermentation index (FI) (FI $=460 / 530$ ) through the analysis of condensed anthocyanins (460 nm and $530 \mathrm{~nm}$ ) was determined by spectrophotometry (Thermo scientific, Helios zeta UV-VIS). Fermented cocoa beans $(0.2 \mathrm{~g})$ were macerated in distilled water and deposited in flat-bottom 9 plastic crates; then, $20 \mathrm{~mL}$ of $\mathrm{CH}_{3} \mathrm{OH}-\mathrm{HCl}$ (97:3) were added. The mixture was homogenized and placed at $8^{\circ} \mathrm{C}$ for $19 \mathrm{~h}$. Subsequently, the mixture was centrifuged for $20 \mathrm{~min}$ at 9,410 x g, and $4^{\circ} \mathrm{C}$ (Heal Force, Neofuge $23 \mathrm{R})$. The supernatant absorbance was calculated at $460 \mathrm{~nm}$ and $530 \mathrm{~nm}$ to determine the FI (Caporaso et al., 2018; Sunoj et al., 2016).

\section{Screening of microorganisms}

Six growth conditions were analyzed to select the most promising isolated candidates to be used in a fermentation starter culture that improves the quality of cocoa beans, considering the fermentation conditions of cocoa beans (i.e., high concentrations of sugars, high acidity, and high temperature). Forty-two isolates (21 yeast, $14 \mathrm{LAB}$, and $7 \mathrm{AAB}$ ) obtained from various cocoa fermentations were subjected to six growth treatments, as follows: high concentrations of $10 \%$ glucose, $5 \%$ ethanol, and $7 \%$ acetic acid, high acidic $\mathrm{pH}(3.0)$, high temperature $\left(50^{\circ} \mathrm{C}\right)$ and $50 \%$ cocoa pulp agar (CPA). Ethanol was added to the culture media after autoclaving. The treatment with a $\mathrm{pH}$ of 3.0 was adjusted with $1 \mathrm{~N} \mathrm{HCL}$, which was added after autoclaving. For the 50\% cocoa pulp treatment, the agar 
and pulp were autoclaved separately and were then mixed in a laminar flow cabinet. Each microorganism suspension was adjusted in sterile saline solution to a McFarland 2 index, and then $10 \mu \mathrm{L}$ of each suspension was placed at four points on the agar. The plates were incubated for $96 \mathrm{~h}$ at $28 \pm 2^{\circ} \mathrm{C}$, and then, the diameters of the colonies were measured. The data was analyzed using an ANOVA, and differences of means were established with an LSD all-pairwise comparisons test and Tukey's HSD all-pairwise comparisons test at $P<0.05$.

\section{Molecular Characterization}

\section{DNA extraction}

DNA was extracted from pure cultures of yeasts, LAB, and AAB. Yeasts were cultured in yeast glucose chloramphenicol broth (YGC) at $30^{\circ} \mathrm{C}$, LAB in MRS broth at $35^{\circ} \mathrm{C}$, and $\mathrm{AAB}$ in $\mathrm{YPGC}$ broth at $35^{\circ} \mathrm{C}$. Two milliliters of each growth culture medium were transferred to microtubes. A quick DNA-Fungal/Bacterial kit for extraction (Zymo Research) was used following the recommended instructions of the manufacturers. The concentration and purity of the DNA were obtained using a Thermo Scientific NanoDrop 2000/2000C spectrophotometer, and then by electrophoresis on $1 \%$ agarose gel.

\section{PCR amplification}

Yeast 18S PCR amplification was performed with some initiators (NL1-F, LR6-R, ITS1-F, ITS1-R) previously used by Rodriguez et al. (2008), for the molecular identification and establishment of a barcode. These sequences are presented in Table 1. The PCR protocol used was performed with $21 \mu \mathrm{L}$ of Taq Ready Mix (Sigma Chemical Company), $1 \mu \mathrm{L}$ of LR6-R/ITS1-R primers,
$1 \mu \mathrm{L}$ of NL1-F/ITS1-F primers, and $2 \mu \mathrm{L}$ of DNA; the process was carried with the following conditions: A denaturation stage that lasted $3 \mathrm{~min}$ at $94^{\circ} \mathrm{C}$ followed by 30 cycles at $94^{\circ} \mathrm{C}$ for $45 \mathrm{~s}, 63^{\circ} \mathrm{C}$ for $40 \mathrm{~s}, 72^{\circ} \mathrm{C}$ for $90 \mathrm{~s}$, and $72^{\circ} \mathrm{C}$ for $10 \mathrm{~min}$. PCR products were visualized after electrophoresis on a $1.5 \%$ agarose gel. Finally, products were sequenced by Corpogen (Bogotá, Colombia) in partnership with Macrogen Korea (export permit number for non-CITES specimens: 01753) (Table 1).

For $\mathrm{LAB}$ and $\mathrm{AAB}, 16 \mathrm{~S}$ rRNA genes were amplified with the same reaction volumes used in the Taq Ready Mix, reverse primer, forward primer and genomic DNA, under the following conditions: $94^{\circ} \mathrm{C}$ for $3 \mathrm{~min}$ followed by 10 cycles of denaturation at $94^{\circ} \mathrm{C}$ for $1 \mathrm{~min}$, annealing at $65^{\circ} \mathrm{C}\left(1^{\text {st }}\right.$ cycle $)$ to $55^{\circ} \mathrm{C}\left(10^{\text {th }}\right.$ cycle $)$ for $1 \mathrm{~min}$, and extension at $72^{\circ} \mathrm{C}$ for $1 \mathrm{~min}$; subsequently, 25 cycles of $94^{\circ} \mathrm{C}$ for $1 \mathrm{~min}, 55^{\circ} \mathrm{C}$ for $1 \mathrm{~min}$, and $72^{\circ} \mathrm{C}$ for $1 \mathrm{~min}$. Finally, an extension to $10 \mathrm{~min}$ was carried out in the last cycle. PCR products were visualized after electrophoresis on a $1.5 \%$ agarose gel. Finally, products were sequenced by Corpogen (Bogotá, Colombia) in partnership with Macrogen Korea (export permit number for non-CITES specimens: 01753).

Table 1. Yeast $18 \mathrm{~S}$ rDNA primers used for sequence identification

\begin{tabular}{ll}
\hline Primer & \multicolumn{1}{c}{ Sequence } \\
\hline NL1-F & 5'-GCATATCAATAAGCGGAGGAAAAG-3' \\
LR6-R & 5'-CGCCAGTTCTGCTTACC-3' \\
ITS1-F & 5'-TCCGTAGGTGAACCTGCGG-3' \\
ITS1-R & 5'-TCCTCCGCTTATTGATATGC-3' \\
\hline
\end{tabular}

\section{RESULTS AND DISCUSSION}

\section{Isolation of Prevalent Species in the Cocoa Fermentation Process}

This study showed an abundant microbial species diversity in cocoa fermentations 
identifying some key strains for their tolerance to heat, high glucose or, ethanol concentration, and acid $\mathrm{pH}$; this is crucial since the cocoa pulp is rich in fermentable sugars (10$15 \%$ ) such as glucose, fructose, and sucrose (Duarte et al., 2010), and has a low pH of 3.0-3.5 mainly due to the presence of citric acid (Ardhana \& Fleet, 2003). These conditions are selective for the initial growth of yeasts and lactic acid bacteria.

On the Rivera (Huila) farm $12 \mathrm{~h}$ after the beginning of the cocoa fermentation, the microbial populations began to increase. The presence of the three different groups reported, i.e., yeast, LAB, and AAB (Figure $1 \mathrm{a}, 1 \mathrm{~b}$, and 1c), were observed from the beginning of the fermentation. Between 48 and $108 \mathrm{~h}$, the highest CFU values for the three groups were recorded with a gradual decrease after $120 \mathrm{~h}$ (Figure 1a). Regarding $\mathrm{pH}$, the cotyledon, testa, and pulp solutions registered the following values at the end of the fermentation, the testas exhibited a $\mathrm{pH}$ of 3.8 at $0 \mathrm{~h}$ of fermentation and reached a pH of 4.4 at the end of the process, while the cotyledons registered an initial $\mathrm{pH}$ of 6.5 and finished with a $\mathrm{pH}$ of 4.2 (Figure $1 b)$. For the municipality of San Vicente de Chucurí (Santander), CFU values at the beginning of the fermentation were higher than those registered in Rivera (Huila). Pulp CFU values were maximum between 60 and $72 \mathrm{~h}$ of fermentation; from this point onwards, the populations decreased (Figure 1c). The $\mathrm{pH}$ values of the testa and pulp solutions were similar; however, the $\mathrm{pH}$ of the cotyledon registered a value of 6.0 at $0 \mathrm{~h}$ and decreased as fermentation progressed to a $\mathrm{pH}$ of 4.1 at $132 \mathrm{~h}$ (Figure 1d). Similarly, microbial populations at the municipality of Maceo (Antioquia) showed high CFU values in the malt extract medium with a decrease after $120 \mathrm{~h}$ of fermentation; the most abundant populations were recorded between 84 and $96 \mathrm{~h}$ (Figure 1e). The behavior of the $\mathrm{pH}$ values for the pulp and cotyledon solutions showed similar values in the Rivera and San Vicente de Chucurí farms at the end of the fermentation, with average $\mathrm{pH}$ values between 4 and 4.5 (Figure 1f). Morphologies were highly diverse, signaling confirmed differences revealed by molecular identifications. Unique isolates passed to the second phase of selection and characterization by specific tests such as resistance to ethanol, acetic acid, temperature, and acidic $\mathrm{pH}$.

The fermentation index (FI) registered at each sampling moment exhibited a similar trend throughout the three regions. Since the FI is a rate between the absorbance at 460 and $530 \mathrm{~nm}$, this relationship was mainly affected by the absorbance values at $530 \mathrm{~nm}$, which were high at the beginning of the fermentation and decreased as the process progressed; on the contrary, the values at $460 \mathrm{~nm}$ remained relatively constant. This trend was observed in the three regions under study. The beans obtained from the Santander region recorded the lowest absorbance values in the two wavelengths under study, which may indicate a lower presence of anthocyanins in the beans of this region (Figure 2). Cotyledon staining is a typical genetic characteristic associated with the cocoa variety. Usually, the anthocyanin content is high at the beginning of the fermentation and decreases as it progresses (Pelaez et al., 2016). 

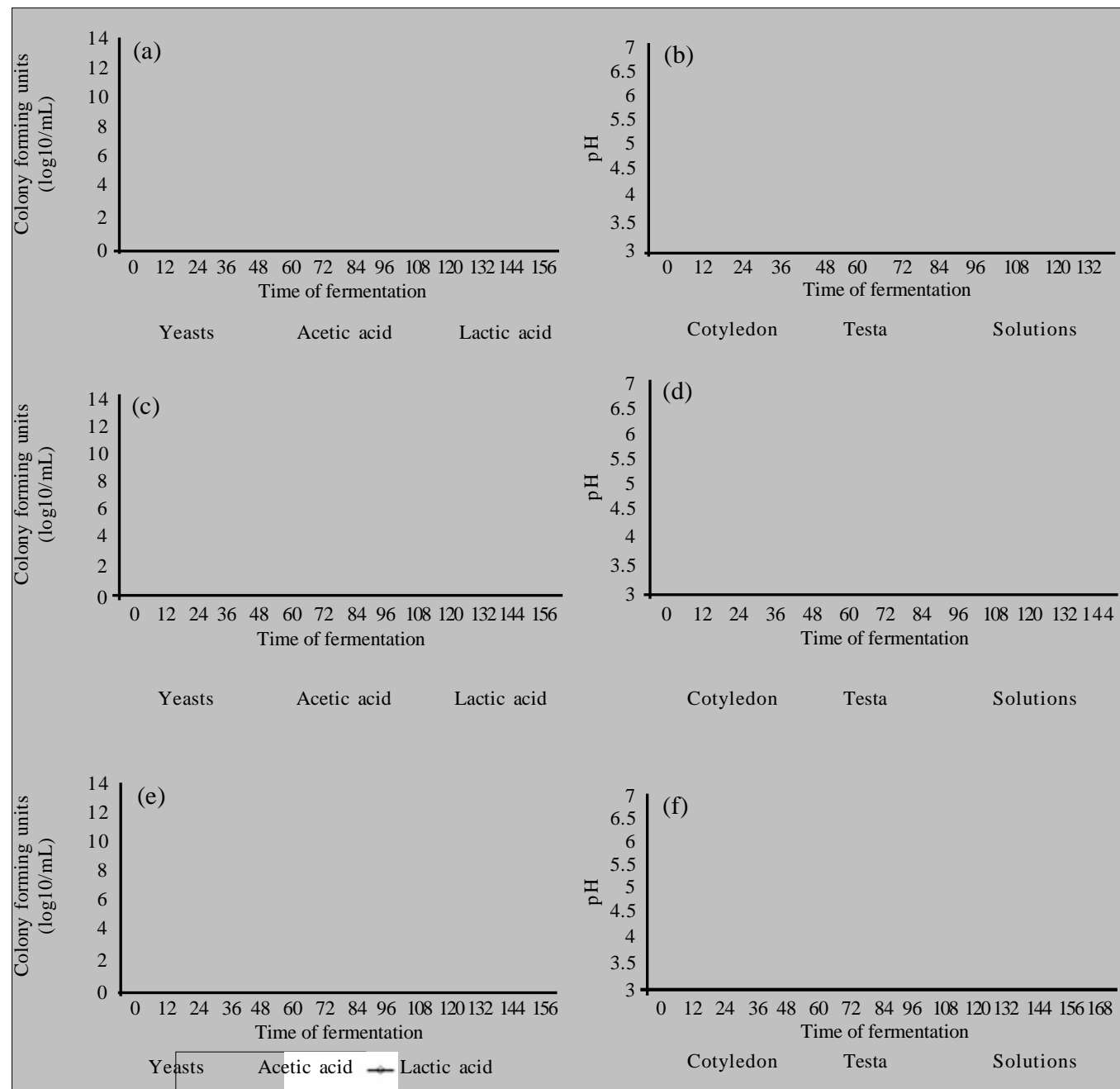

Figure 1. Dynamics of the cocoa fermentation (colony forming units $(\log 10 \mathrm{CFU} / \mathrm{mL})$ ) and $\mathrm{pH}$ from the beginning to the end of the process; a. $\log 10 \mathrm{CFU} / \mathrm{mL}$ for yeasts, lactic acid bacteria (LAB), and acetic acid bacteria (AAB) (municipality of Rivera, Huila), b. Culture $\mathrm{pH}$ for cotyledon, testa, and pulp solutions (municipality of Rivera, Huila), c. Log10 CFU/mL for yeasts, LAB, and AAB (San Vicente de Chucurí, Santander), d. Culture $\mathrm{pH}$ for cotyledon, testa, and pulp solutions (San Vicente de Chucurí, Santander), e. $\log 10 \mathrm{CFU} / \mathrm{mL}$ for yeasts, $\mathrm{LAB}$, and AAB (Maceo, Antioquia), and f. Culture $\mathrm{pH}$ for cotyledon, testa and pulp solutions (Maceo, Antioquia).
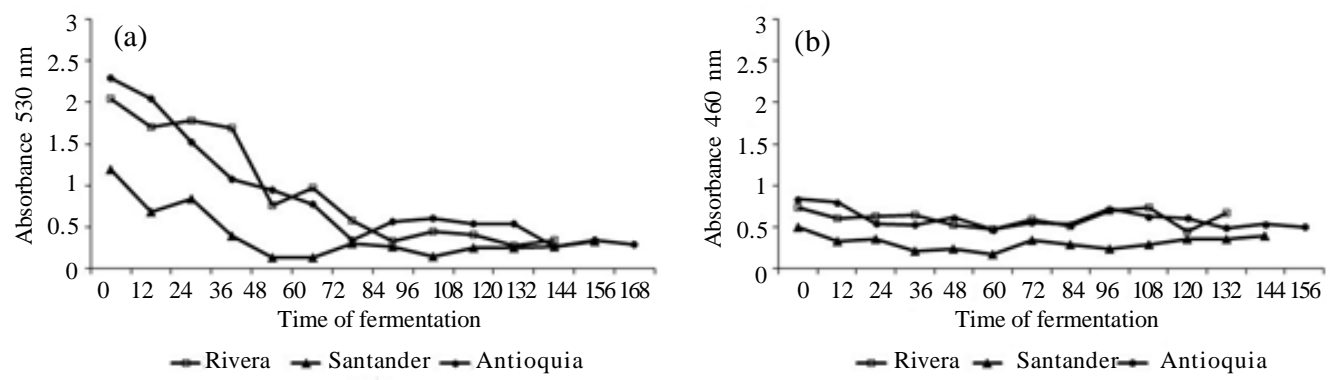

Figure 2. Absorbance values $530 \mathrm{~nm}$ (a), and $460 \mathrm{~nm}$ (b) from supernatants obtained from fermented and dried cocoa beans in three sampled regions of Colombia during the entire fermentation process 


\section{Selection of Microorganisms by Physicochemical Parameters}

Resistance testing is the most widely accepted practice for the selection of the group of microorganisms that comprise a microbiological initiator culture, guaranteeing in this way its permanence during the fermentation phase. This is the reason why each of the conditions surrounding this process must be evaluated to select the best strains.

Twenty-one isolates obtained from different cocoa fermentation processes in the three regions identified as yeasts were subjected to various growth analysis tests (Table 2). All the yeast isolates (100\%) grew on agar medium supplemented with $10 \%$ glucose. Isolates 77, 88, 90, and 93 showed the largest colonies $\left(\mathrm{F}_{20.83}=8.63 ; p=0.000\right)$ on $10 \%$ glucose medium. The growth of isolates 63 , 73,77 , and 87 on $5 \%$ ethanol-supplemented agar was superior $\left(\mathrm{F}_{20.83}=130.43 . p=0.000\right)$ compared to the other isolates; however, $85.7 \%$ of the yeast isolates grew on this medium. All the yeast isolates were inhibited by $7 \%$ acetic acid, and $100 \%$ of the yeast isolates grew on CPA; however, in descending order, isolates 85,92 , and 97 grew best in this medium $\left(\mathrm{F}_{20.83}=7.37 . p=0.000\right)$. Growth was stimulated $\left(\mathrm{F}_{20,83}=9.10_{;} p=0.000\right)$ in isolates 94,97 , and 99 when cultured in a medium with an acidic $\mathrm{pH}$ of 3.0; on the contrary, isolate 88 exhibited no growth at this $\mathrm{pH}$ (Table 2).

In medium selective for $\mathrm{LAB}, 14$ identified isolates were subjected to growth analysis tests (Table 3). Isolates 6, 13, 24, 46, and 314 showed high growth $\left(\mathrm{F}_{13,55}=3.79\right.$; $\left.p=0.0005\right)$ in $10 \%$ glucose medium, whereas isolates 56 and 315 showed no growth. All isolates grew in 5\% ethanol medium, while isolates $12,24,34,308$, and 309 showed numerically higher values but with no statistical differences. Six isolates, 12, 13, 24, 34, 44 and 56, showed growth in CPA $\left.\left(\mathrm{F}_{13.55}=61.46\right): p=0.000\right)$, while nine isolates, $7,13,24,34,44,56,308$, 314 and 315 , showed growth at a $\mathrm{pH}$ of 3.0 $\left.\left(\mathrm{F}_{13.55}=23.73\right)_{;} p=0.000\right)$. Further, five isolates, $6,12,13,34$ and 44 , subjected to $50^{\circ} \mathrm{C}$ for $24 \mathrm{~h}$ were tolerant to this temperature $\left(\mathrm{F}_{13,55}\right.$ $=120.05$ : $p=0.000$ ).

Table 2. Yeast colony diameters ${ }^{1)}$ of isolates obtained from several cocoa fermentation processes in three regions of Colombia cultured on agar media subjected to different treatments

\begin{tabular}{|c|c|c|c|c|c|c|c|}
\hline Number & Isolate & $\begin{array}{l}\text { Glucose } \\
(10 \%)\end{array}$ & $\begin{array}{c}\text { Ethanol } \\
(5 \%)\end{array}$ & $\begin{array}{c}\text { Acetic acid } \\
(7 \%)\end{array}$ & CPA & $\mathrm{pH} 3$ & $50^{\circ} \mathrm{C}$ \\
\hline 62 & Wickerhamomyces anomalus & $11.20 \mathrm{fg}$ & $0.0 \mathrm{j}$ & 0 & $6.16 \mathrm{i}$ & $11.13 \mathrm{de}$ & 0 \\
\hline 63 & Wickerhamomyces anomalus strain ADJ2 & $9.32 \mathrm{~g}$ & $8.28 \mathrm{bc}$ & 0 & 7.65 cdefg & $8.31 \mathrm{efg}$ & 0 \\
\hline 65 & Wickerhamomyces anomalus & $9.34 \mathrm{~g}$ & $0.0 \mathrm{j}$ & 0 & 7.93 cdefg & $5.27 \mathrm{~g}$ & 0 \\
\hline 66 & Wickerhamomyces anomalus & $10.67 \mathrm{fg}$ & $8.09 \mathrm{bc}$ & 0 & $7.27 \mathrm{fgh}$ & 11.50 cde & 0 \\
\hline 67 & Debaryomyces hansenii strain $\mathrm{YE} 3$ & $13.95 \mathrm{def}$ & 6.65 hi & 0 & 8.38 bcde & $10.43 \mathrm{de}$ & 0 \\
\hline 73 & Meyerozyma guilliermondii & $11.17 \mathrm{fg}$ & $8.73 a b$ & 0 & $8.60 \mathrm{bcd}$ & $10.40 \mathrm{de}$ & 0 \\
\hline 77 & Pichia manshurica strain CBS 11610 & $20.46 \mathrm{bc}$ & $9.19 \mathrm{a}$ & 0 & $7.68 \mathrm{cdfg}$ & $9.94 \mathrm{de}$ & 0 \\
\hline 78 & Debaryomyces hansenii & $11.96 \mathrm{fg}$ & 7.80 cde & 0 & 7.54 defgh & 10.17 de & 0 \\
\hline 81 & Meyerozyma guilliermondii & $18.79 \mathrm{bc}$ & $0.0 \mathrm{j}$ & 0 & $6.84 \mathrm{ghi}$ & $10.35 \mathrm{de}$ & 0 \\
\hline 84 & Candida stellimalicola strain NRRL & $19.87 \mathrm{bc}$ & $7.10 \mathrm{fgh}$ & 0 & 7.39 efgh & $6.13 \mathrm{fg}$ & 0 \\
\hline 85 & Candida parapsilosis strain $\mathrm{CDC} 317$ & $19.08 \mathrm{bc}$ & 7.77 cdef & 0 & $10.85 \mathrm{a}$ & $13.33 \mathrm{bcd}$ & 0 \\
\hline 87 & Meyerozyma guilliermondii & 17.13 cde & $8.22 \mathrm{bc}$ & 0 & $8.58 \mathrm{bcd}$ & $10.45 \mathrm{de}$ & 0 \\
\hline 88 & Meyerozyma guilliermondii & $22.05 \mathrm{ab}$ & $6.25 \mathrm{i}$ & 0 & 7.18 fghi & $0.0 \mathrm{~h}$ & 0 \\
\hline 89 & Meyerozyma guilliermondii & $10.04 \mathrm{fg}$ & $6.82 \mathrm{ghi}$ & 0 & 7.56 defgh & 9.17 ef & 0 \\
\hline 90 & Meyerozyma guilliermondii & $20.58 \mathrm{bc}$ & $8.03 \mathrm{~cd}$ & 0 & $8.63 \mathrm{bcd}$ & $11.30 \mathrm{de}$ & 0 \\
\hline 92 & Meyerozyma guilliermondii & $11.77 \mathrm{fg}$ & $7.97 \mathrm{~cd}$ & 0 & $9.47 \mathrm{~b}$ & $10.73 \mathrm{de}$ & 0 \\
\hline 93 & Meyerozyma guilliermondii & $25.14 \mathrm{a}$ & 7.13 efgh & 0 & $6.92 \mathrm{ghi}$ & $7.91 \mathrm{efg}$ & 0 \\
\hline 94 & Pichia guilliermondii & $13.37 \mathrm{efg}$ & $6.97 \mathrm{gh}$ & 0 & $6.48 \mathrm{hi}$ & $15.23 \mathrm{bc}$ & 0 \\
\hline 95 & Meyerozyma guilliermondii & $18.45 \mathrm{bcd}$ & $7.37 \mathrm{defg}$ & 0 & 8.24 cdef & $13.55 \mathrm{bcd}$ & 0 \\
\hline 97 & Meyerozyma guilliermondii & 16.56 cde & 7.82 cde & 0 & $8.70 \mathrm{bc}$ & $19.07 \mathrm{a}$ & 0 \\
\hline 99 & Meyerozyma guilliermondii & $13.59 \mathrm{efg}$ & $7.38 \mathrm{defg}$ & 0 & $7.61 \mathrm{cdefg}$ & $16.89 \mathrm{ab}$ & 0 \\
\hline
\end{tabular}


Seven isolates were characterized as acetic acid bacteria, with isolates 310,312 , and 313 exhibiting significant growth $\left(\mathrm{F}_{6,27}\right.$ $=14.72 . p=0.000)$ in the $10 \%$ glucose medium (Table 4). In the 5\% ethanol medium, five isolates showed some growth, while two were inhibited $\left(\mathrm{F}_{6,27}=75.27 ; p=\right.$ $0.000)$. In the $7 \%$ acetic acid medium, all isolates showed growth; however, isolates 287 and 307 presented the largest colonies $\left(\mathrm{F}_{6,27}=5.30 ; p=0.0018\right)$. Is olate 287 showed the largest growth $(P<0.05)$ in CPA medium $\left(\mathrm{F}_{6,27}=19.57_{;} p=0.000\right)$, while isolate 312 exhibited the largest growth in an acidic medium with a $\mathrm{pH}$ of $3.0\left(\mathrm{~F}_{6,27}=9.03 p=0.0001\right)$. No isolates grew when subjected to $50^{\circ} \mathrm{C}$.
The fermentation of cocoa pulp increases the temperature during the exothermic production of acetic acid, helping to decrease the pulp cells of the cocoa beans (Nielsen et al., 2007). Consequently, enzymes responsible for the degradation of sugars, amino acids, and peptides contribute to the release of volatile compounds related to flavor and aroma precursors. Some studies (of Meersman et al., 2015a,b) carried out with tolerant yeasts at high temperatures indicate that they are suitable for starter cultures as they can suppress the growth of the native cocoa microbiota and improve the quality of the final product. Some authors denote that thermotolerance is a decisive factor for the effectiveness of a microbiological initiator culture (Meersman et al., 2015a).

Table 3. Lactic acid bacteria colony diameters ${ }^{1}$ of isolates obtained from several cocoa fermentation processes in three regions of Colombia cultured on agar media subjected to different treatments

\begin{tabular}{|c|c|c|c|c|c|c|c|}
\hline Number & Isolate & $\begin{array}{c}\text { Glucose } \\
(10 \%)\end{array}$ & $\begin{array}{c}\text { Ethanol } \\
(5 \%)\end{array}$ & $\begin{array}{c}\text { Acetic acid } \\
(7 \%)\end{array}$ & CPA & $\mathrm{pH} 3$ & $50^{\circ} \mathrm{C}$ \\
\hline 6 & Pediococcus acidilactici & $26.60 \mathrm{a}$ & $14.30 \mathrm{a}$ & 0 & $0.0 \mathrm{c}$ & $0.0 \mathrm{e}$ & $16.34 \mathrm{c}$ \\
\hline 7 & Pediococcus acidilactici & $18.95 \mathrm{ab}$ & $17.59 \mathrm{a}$ & 0 & $0.0 \mathrm{c}$ & $18.89 \mathrm{bcd}$ & $0.0 \mathrm{~d}$ \\
\hline 12 & Pediococcus acidilactici & $24.26 \mathrm{ab}$ & $29.93 \mathrm{a}$ & 0 & $7.45 \mathrm{~b}$ & $0.0 \mathrm{e}$ & $32.29 \mathrm{a}$ \\
\hline 13 & Pediococcus acidilactici & $30.83 \mathrm{a}$ & $24.59 \mathrm{a}$ & 0 & $9.04 \mathrm{ab}$ & $29.70 \mathrm{ab}$ & $28.05 \mathrm{ab}$ \\
\hline 24 & Lactobacillus brevis & $25.80 \mathrm{a}$ & $26.17 \mathrm{a}$ & 0 & $11.75 \mathrm{a}$ & $4.44 \mathrm{e}$ & $0.0 \mathrm{~d}$ \\
\hline 34 & Leuconostoc mesenteroides & $17.18 \mathrm{ab}$ & $25.12 \mathrm{a}$ & 0 & $7.49 \mathrm{~b}$ & $25.39 \mathrm{ab}$ & $24.15 \mathrm{~b}$ \\
\hline 44 & Pediococcus acidilactici & $21.97 \mathrm{ab}$ & $24.47 \mathrm{a}$ & 0 & $8.83 a b$ & $23.39 \mathrm{ab}$ & $28.00 \mathrm{ab}$ \\
\hline 46 & Lactobacillus farraqinis & $28.34 \mathrm{a}$ & $16.63 \mathrm{a}$ & 0 & $0.0 \mathrm{c}$ & $0.0 \mathrm{e}$ & $0.0 \mathrm{~d}$ \\
\hline 56 & Lactobacillus plantarum & $0.0 \mathrm{~b}$ & $12.62 \mathrm{a}$ & 0 & $11.18 \mathrm{a}$ & 9.53 cde & $0.0 \mathrm{~d}$ \\
\hline 209 & Lactobacillus rhamnosus & $20.50 \mathrm{ab}$ & $13.02 \mathrm{a}$ & 0 & $0.0 \mathrm{c}$ & $0.0 \mathrm{e}$ & $0.0 \mathrm{~d}$ \\
\hline 308 & Lactobacillus plantarum & $23.85 \mathrm{ab}$ & $30.50 \mathrm{a}$ & 0 & $0.0 \mathrm{c}$ & $21.22 \mathrm{bc}$ & $0.0 \mathrm{~d}$ \\
\hline 309 & Lactobacillus plantarum & $19.22 \mathrm{ab}$ & $27.15 \mathrm{a}$ & 0 & $0.0 \mathrm{c}$ & $0.0 \mathrm{e}$ & $0.0 \mathrm{~d}$ \\
\hline 314 & Lactobacillus plantarum & $30.53 \mathrm{a}$ & $22.09 \mathrm{a}$ & 0 & $0.0 \mathrm{c}$ & $35.38 \mathrm{a}$ & $0.0 \mathrm{~d}$ \\
\hline 315 & Lactobacillus plantarum & $0.0 \mathrm{~b}$ & $10.05 \mathrm{a}$ & 0 & $0.0 \mathrm{c}$ & 7.44 de & $0.0 \mathrm{~d}$ \\
\hline
\end{tabular}

Notes: ${ }^{1}$ Mean diameter $(\mathrm{mm}), \mathrm{n}=4$ (growth of four colonies); Means in columns and with the same superscript are not significantly different $(P>0.05)$.

Table 4. Acetic acid bacteria colony diameters ${ }^{1)}$ of isolates obtained from several cocoa fermentation processes in three regions of Colombia cultured on agar media subjected to different treatments

\begin{tabular}{llcrrrrr}
\hline \multirow{2}{*}{ Number } & \multicolumn{1}{c}{ Isolate } & $\begin{array}{c}\text { Glucose } \\
(10 \%)\end{array}$ & $\begin{array}{c}\text { Ethanol } \\
(5 \%)\end{array}$ & $\begin{array}{c}\text { Acetic acid } \\
(7 \%)\end{array}$ & CPA & pH 3 & $50^{\circ} \mathrm{C}$ \\
\hline 286 & Gluconobacter sp. LBN175 & $14.28 \mathrm{c}$ & $0.0 \mathrm{c}$ & $11.87 \mathrm{abc}$ & $8.84 \mathrm{~b}$ & $10.87 \mathrm{~b}$ & 0 \\
287 & Gluconobacter japonicus & $19.60 \mathrm{bc}$ & $0.0 \mathrm{c}$ & $12.43 \mathrm{a}$ & $17.67 \mathrm{a}$ & $12.59 \mathrm{~b}$ & 0 \\
307 & Acetobacter tropicalis & $24.54 \mathrm{bc}$ & $20.95 \mathrm{a}$ & $12.56 \mathrm{a}$ & $8.14 \mathrm{~b}$ & $10.91 \mathrm{~b}$ & 0 \\
310 & Acetobacter tropicalis & $37.88 \mathrm{a}$ & $14.60 \mathrm{~b}$ & $9.44 \mathrm{c}$ & $10.36 \mathrm{~b}$ & $14.95 \mathrm{~b}$ & 0 \\
311 & Acetobacter pasteurianus/pomorum & $19.79 \mathrm{bc}$ & $14.83 \mathrm{~b}$ & $10.68 \mathrm{abc}$ & $8.14 \mathrm{~b}$ & $12.35 \mathrm{~b}$ & 0 \\
312 & Acetobacter tropicalis & $35.83 \mathrm{a}$ & $19.91 \mathrm{a}$ & $9.80 \mathrm{bc}$ & $8.05 \mathrm{~b}$ & $24.41 \mathrm{a}$ & 0 \\
313 & Acetobacter malorum/tropicalis & $29.71 \mathrm{ab}$ & $14.54 \mathrm{~b}$ & $12.08 \mathrm{ab}$ & $7.97 \mathrm{~b}$ & $11.67 \mathrm{~b}$ & 0 \\
\hline
\end{tabular}

Notes: ${ }^{1)}$ Mean diameter $(\mathrm{mm}), \mathrm{n}=4$ (growth of four colonies). Means in columns and with the same superscript are not significantly different $(P>0.05)$. 


\section{Molecular Characterization}

The sequence analysis of the yeast isolates showed that six correspond to the species C. parapsilosis $(68,72,76,83,85$, and 98$)$, three are $D$. hansenii $(67,75$, and 78$), 13$ are M. guillermondii $(73,81,87,88,89,90,91$, $92,93,94,95,97$, and 99), four are $W$. anomalus (62, 63, 65, and 66), one is P. manshurica (77), one is C. stellimalicota (84), one is $P$. guillermondii (94), and three are T. asahii (64, 66, and 71). The characterization of LAB also registered high diversity. Sequence identification revealed that some isolates correspond to the species $P$. acidilactici (6, 7, 13, and 44), L. brevis (24), L. plantarum (56, 308, 309, 314, and 315), L. farraginis (46), L. rhamnosus (209), and L. mesenteroides (34). In the AAB group, some isolates belong to the species Gluconobacter sp. (286), G. japonicus (287), A. tropicalis (307, 310, and 312), A. pasteurianus/pomorum (311), and A. malorum/tropicalis (313). Some isolates were identified as B. aryabhattai/megaterium (319), B. subtilis (320, 321, and 322) and B. coagulans (316).

About $40 \%$ of the isolates obtained have been reported in previous studies of population identification in cocoa fermentation. The presence of all these species in the cocoa fermentation mixtures is of great importance because they are internationally referenced as beneficial organisms that produce prebiotics, antibiotics, and B12 vitamin, as is the case with B. megaterium (Tortoló \& Bell, 2015). Pediococcus acidilactici is commonly found in fermented vegetables, dairy products and meat (Barros et al., 2001); it is classified as probiotic (Standen et al., 2013; Merrifield, 2013) and its bacteriocins have been evaluated for the control of Listeria monocytogenes (García et al., 2017). L. brevis is a fermentative bacterium that produces $\mathrm{CO}_{2}$ and lactic acid, and can be found in numerous and different environments such as fermented foods; it has anti-inflammatory effects in periodontal illnesses (Della Riccia et al., 2007), probiotic properties (Ronka et al., 2003; Mancini \& Fava, 2016), and has been reported as being able to control the growth of Escherichia coli and Salmonella (Syukur et al., 2013). Furthermore, it has been detected in cocoa fermentation studies. L. plantarum exhibits antifungal activity (Lavermicocca et al., 2000; Strom et al., 2002) and has been used in the treatment of illnesses produced by Clostridium difficile (Wullt et al., 2003) and colitis (Schultz et al., 2002). L. plantarum has probiotic potential and reduces the effects of cholesterol (Nguyen et al., 2007). This bacterium was previously reported by Lefeber et al. (2011) as being associated with cocoa fermentation. $D$. hansenii that has beneficial effects as it participates in maturation processes producing ethanol, $\mathrm{CO}_{2}$, and a great variety of volatile compounds such as alcohols, esters, ketones, aldehydes and sulphuretted compounds that promote flavor and final aroma (Boekhout \& Pfaff, 2003). D. hansenii can be found in products with high sugar content, and as it is osmotolerant, it is incredibly advantageous for some biotechnical applications (Breuer \& Harms, 2006); further, it has been registered in several cocoa fermentation mixtures (Camu et al., 2008). W. anomalus is a nonSaccharomyces yeast found in wine fermentation that contributes to the aroma through the production of volatile compounds. In recent years, this yeast has been used as a biological control agent against fungi due to its capacity to produce mycotoxins (Coda et al., 2011). Meyerozyma guillermondii has been characterized as having antifungal features, as a phosphate solubilizer in soils (Nakayan et al., 2013), and it has also been associated with cocoa fermentations (de Melo et al., 2013). The yeast $M$. guilliermondii was identified in two of the monitored regions, Maceo (Antioquia) and San Vicente de Chucurí (Santander). Most of the isolates 
of this genus showed good growth in high concentrations of $10 \%$ glucose. D. hansenii was reported in Rivera (Huila) and San Vicente de Chucurí (Santander). The two isolates of this genus grew well in the growth tests and were, therefore, candidates to be included in a cocoa fermentation starter culture. W. anomalus isolates were detected only in Rivera (Huila), two of which had acceptable development in growth tests, being equally selected as candidates for a microbial starter culture for cocoa bean fermentation.

Regarding the LAB, isolates of $P$. acidilactici were detected at the three fermentation locations. Some LAB isolates showed good growth in all the evaluation media, including $50^{\circ} \mathrm{C}$ for $24 \mathrm{~h}$, showing to be resistant to this high temperature. L. plantarum was present in fermentation mixtures from Algeciras (Huila) and Maceo (Antioquia). Species such as L. rhamnosus and L. farraginis have been reported as probiotics in the cocoa fermentation process (Moreira et al., 2013). Some isolates of this species showed good growth in $10 \%$ glucose, $5 \%$ ethanol, and at a $\mathrm{pH}$ of 3.0. L. brevis was isolated only at San Vicente de Chucurí (Santander); the isolate grew well in $10 \%$ glucose, $5 \%$ ethanol, $50 \%$ CPA and at a $\mathrm{pH}$ of 3.0, and, therefore, the three isolates belonging to this species were selected as promising to be included in a microbial starter culture for cocoa bean fermentation.

The AAB isolates showed good growth in $10 \%$ glucose. Isolates of A. tropicalis, A. malorum, and $A$. pasteurianus grew well in all media except for $50^{\circ} \mathrm{C}$ for $24 \mathrm{~h}$, whereas isolates of the Gluconobacter genus did not grow in $5 \%$ ethanol or after exposure to $50^{\circ} \mathrm{C}$ for $24 \mathrm{~h}$. The isolates of this group were the only ones that grew in $7 \%$ acetic acid medium. The AAB A. tropicalis, A. pasteurianus/pomorum, and A. malorum are found in sugar-rich fruit, flower, and vegetable substrates. These bacteria are found in vinegar production and have been reported in wine and cocoa fermentations
(Navarro et al., 2013; Moens et al., 2014). A representative of each species was selected as promising to be included in a microbial starter culture.

\section{CONCLUSIONS}

The population dynamics of microorganisms from the three farms were similar. At all times during the monitoring, populations of yeasts, lactic acid bacteria, and acetic acid bacteria were recorded. High species diversity of microorganisms with internationally registered beneficial characteristics were found, such as $P$. acidilactici, L brevis, L plantarum, L. farraginis, L. rhamnosus, Gluconobactersp., G. japonicus, A. tropicalis, A. pasteurianus/pomorum, A. malorum/tropicalis, D. hansenii, M. guillermondii, W. anomalus, B. megaterium and B. subtilis. However, microorganisms considered as pathogens were also found, such as Penicillium spp., Aspergillus spp., E. hirae, E. hormaechei, and G. parapsilosis. Therefore, it is necessary to establish standardization methodologies for cocoa fermentation to improve the nutritional safety and quality conditions of cocoa beans. The temperature of $50^{\circ} \mathrm{C}$ limited the growth of the isolates and inhibited the growth of yeasts and acetic acid bacteria completely; on the contrary, $28 \%$ of the lactic acid bacteria isolates showed resistance to this temperature. Under cocoa fermentation conditions, the tolerant lactic acid isolates corresponded to the species $P$. acidilactici. All acetic acid bacteria isolates grew in $7 \%$ acetic acid medium, while yeast isolates were completely inhibited by $7 \%$ acetic acid and exposure to $50^{\circ} \mathrm{C}$ for $24 \mathrm{~h}$. The strains of the species $W$. anomalus, $D$. hansenii, M. guillermondii, P. acidilactici, L. brevis, L. plantarum, A. tropicalis, A. pasteurianus and G. japonicus are the most promising to be included in a microbial starter culture for cocoa bean fermentation to improve the organoleptic quality of cocoa. 


\section{ACKNOWLEDGMENTS}

We want to thank Dr. Michael Hume for revising the manuscript. We are also grateful to Dr. Jenifer Criollo and Mrs. Ana Gladys Barreto of Agrosavia for their technical assistance. Finally, we wish to thank the publication editor of AGROSAVIA, Liliana Gaona Garcia, for her valuable help with the style correction.

Funding: This work was supported by Corporación Colombiana de Investigación Agropecuaria - AGROSAVIA, and Ministerio de Agricultura y Desarrollo Rural de Colombia (MADR).

\section{REFERENCES}

Ardhana, M.M. \& G.H. Fleet (2003). The microbial ecloogy of cocoa bean fermentations in Indonesia. International Journal of Food Microbiology, 86, 87-99.

Barros, R.R.; M.D. Carvalho; J.M. Peralta; R.R. Facklam \& L.M. Teixeira (2001). Phenotypic and genotypic characterisation of Pediococcus strains isolated from human clinical sources. Journal of Clinical Microbiology, 39, 1241-1246.

Boekhout, T. \& J. Phaff (2003). Yeast biodiversity. p. 1-29. In: Yeasts in Food, Beneficial and Detrimental Aspects (T. Boekhout \& V. Robert, Eds.), CRC Press, Florida.

Breuer, U. \& H. Harms (2006). Debaryomyces hansenii-an extremophilic yeast with biotechnological potential. Yeast, 23, 415-437.

Camu, N.; T.De Winter, N.; T.; S.K. Addo; J.S. Takrama; H. Bernaert \& L. De Vuyst (2008). Fermentation of cocoa beans: influence of microbial activities and polyphenol concentrations on the flavour of chocolate. Journal of the Science of Food and Agriculture, 88, 2288-2297.

Caporaso, N.; M. Whitworth; M. Fowler \& I. Fisk (2018). Hyperspectral imaging for non-destructive prediction of fermen- tation index, polyphenol content and antioxidant activity in single cocoa beans. Food Chemistry, 258, 343-351.

Coda, R.; A. Cassone; C.G. Rizzello; L. Nionelli; G. Cardinali \& M. Gobbetti (2011). Antifungal activity of Wickerhamomyces anomalus and Lactobacillus plantarum during sourdough fermentation: identification of novel compounds and longterm effect during storage of wheat bread. Applied and Environmental Microbiology, 77, 3484-3492.

Della Riccia, D.N.; F. Bizzini; M. Perilli; A. Polimeni; V. Trinchieri; G. Amicosante \& M. Cifone (2007). Anti-inflammatory effects of Lactobacillus brevis (CD2) on periodontal disease. Oral Diseases, 13, 376-385.

De Melo, G.V.; K.T. Magalhaes; E.G. de Almeida; I. DaSilva \& R.F. Schwan (2013). Spontaneus cocoa bean fermentation carried out in a novel-desing stainless Steel tank: influence on the dynamics of microbial populations and physical-chemical properties. International Journal of Food Microbiology, 161, 121-133.

De Vuyst, L.; T. Lefeber; Z. Papalexandratou \& N. Camu (2010). The functional role of lactic acid bacteria in cocoa bean fermentation. p. 301-25. In: Biotechnology of Lactic Acid Bacteria: Novel Applications (F. Mozzi; R.R Raya \& G.M. Vignolo, Eds.), Wiley-Blackwell, Oxford.

De Vuyst, L. \& S. Weckx (2016). The cocoa bean fermentation process: from ecosystem analysis to starter culture development. Journal of Applied Microbiology, 121, 5-17.

Duarte, W.F.; D.R. Dias; J.M. Oliveira; J.A. Teixeira; J.B. Almeida \& R.F. Schwan (2010). Characterizarion of different fruit wines made from cacao, cupuassu, gabiroba, jaboticaba and umbu. LWT - Food Science and Technology, 43, 1564-1572.

Freitas, S. (1998). Cocoa fermentations conducted with a defined microbial cocktail inoculum. Applied and Environmental Microbiology, 64, 1477-1483. 
García, J.M.; S.M. Castro; R. Casquete; J. Silva; R. Queirós; J.A. Saraiva \& P. Teixeira (2017). Enhancement of bacteriocin production and antimicrobial activity of Pediococcus acidilactici HA-6111-2. Acta Aliment Hung, 46, 92-99.

Guerber, J.C.; B. Liu \& J.C. Correll (2003). Characterization of diversity in Colletotrichum acutatum sensu lato by sequence analysis of two gene introns, mtDNA and intro RFLPs, and mating compatibility. Mycologia, 95, 872-895.

Hansen, C.E; M. Del Olmo \& C. Burri (1998). Enzyme activities in cocoa beans during fermentation. Journal of the Science of Food and Agriculture, 77, 273-281.

Ho, V.T.; J. Zhao \& G. Fleet (2014). Yeast are essential for cocoa bean fermentation. International Journal of Food Microbiology, 174, 72-82.

Lavermicocca, P.; F. Valerio; A. Evidente; S. Lazzaroni; A. Corsetti \& M. Gobbetti (2000). Purification and characterization of novel antifungal compounds from the Sourdough Lactobacillus plantarum Strain 21 B. Applied and Environmental Microbiology, 66, 4084-4090.

Lefeber, T.; W. Gobert; G. Vrancken; N. Camu \& L.D. Vuyst (2011). Dynamics and species diversity of communities of lactic acid bacteria and acetic acid bacteria during spontaneous cocoa bean fermentation in vessels. Food Microbiology, $28,457-464$.

Lefeber, T.; Z. Papalexandratou; W. Gobert; N. Camu \& L. De Vuyst (2012). On-farm implementation of a starter culture for improved cocoa bean fermentation and its influence on the flavour of chocolates produced thereof. Food Microbiology, 30, 379-392.

Lima, L.J.R.; M.H. Almeida; M.J. Rob Nout \& M.H. Zwietering (2011). Theobroma cacao L., "the food of the gods": Quality determinants of commercial cocoa beans, with particular reference to the impact of fermentation. Critical Reviews in Food Science and Nutrition, 51, 731-761.

López, M.; J. Criollo; M. Hernández; M.D. LozanoTovar (2019). Physicochemical and microbiological dynamics of the fermentation of the CCN51 cocoa material in three maturity stages. Revista Brasileira de Fruticultura, 41, 1-13.

Mancini, A. \& F. Fava (2016). Probiotic potential of a high GABA producing strain, Lactobacillus brevis FEM 1874, isolated from traditional "wild" Alpine cheese. Journal of Clinical Gastroenterology, 50, 220-221.

Meersman, E.; J. Steensels; N. Struyt; T. Paulus; V. Saels; M. Mathawan; L. Allegaert; G. Vrancken \& K. Verstrepen (2015a). Tuning chocolate flavor through development of thermotolerant Saccharomyces cerevisiae starter cultures with increased acetate ester production. Applied and Environmental Microbiology, 82, 732-746.

Meersman, E.; J. Steensels; T. Paulus; N. Struyf; V. Saels; M. Mathawan \& K.J. Verstrepen (2015). Breeding strategy to generate robust yeast starter cultures for cocoa pulp fermentations. Applied and Environmental Microbiology, 81, 6166-6176.

Merrifield, D.L. (2013). Probiotic Pediococcus acidilactici modulates both localised intestinal-and peripheral-immunity in tilapia (Oreochromis niloticus). Fish and Shellfish Immunology, 35, 1097-1104.

Moens, F.; T. Lefeber \& L. De Vuyst (2014). Oxidation of metabolites highlights the microbial interactions and role of Acetobacter pasteurianus during cocoa bean fermentation. Applied and Environmental Microbiology, 80, 1848-1857.

Moreira, I.M.; M.G. Miguel; W.F. Duarte; D.R. Dias \& R.F. Schwan (2013). Microbial succession and the dynamics of metabolites and sugars during the fermentation of three different cocoa (Theobroma cacao L.) hydrids. Food Research International, 54, 9-17. 
Nakayan, P.; A. Hameed; S. Singh; L. Young; M. Hung \& C. Youn (2013). Phosphatesolubilizing soil yeast Meyerozyma guillermondii $\mathrm{CC} 1$ improves maize (Zea mays L.) productivity and minimizes requisite chemical fertilization. Plant and Soil, 373, 1-2.

Navarro, D.; E. Mateo; M. Torija \& A. Mas (2013). Acetic acid bacteria in grape must. Acetic Acid Bacteria, 2, 19-23.

Nguyen, T.D.; J.H. Kang \& M.S. Lee (2007). Characterization of Lactobacillus plantarum $\mathrm{PHO}$, a potential probiotic bacterium with cholesterol-lowering effects. International Journal of Food Microbiology, 113, 358-361.

Nielsen, D.S.; O.D. Teniola; L. Ban-Koffi; M. Owusu; T.S. Andersson \& W.H. Holzapfel (2007). The microbiology of Ghanaian cocoa fermentations analysed using culturedependent and culture-independent methods. International Journal of Food Microbiology, 114, 168-186.

Ohmori, S.; T. Uozumi \& T. Beppu (1982). Loss of acetic acid resistence and etanol oxidizing ability in an Acetobacter strain. Agricultural and Biological Chemistry, 46, 381-389.

Pelaez, P.; S. Guerra \& D. Contreras (2016). Changes in physical and chemical characteristics of fermented cocoa (Theobroma cacao) beans with manual and semi-mechanized transfer, between fermentation boxes. Scientia Agropecuaria, 7, 111-119.

Rodríguez, S.Y. (2008). Identificación molecular y establecimiento del código de barras, Bar Code, de levaduras nativas. Pontificia Universidad Javeriana - Puj - Sede Bogotá.

Ronka, E.; E. Malinen; M. Saarela; M. RintaKoski; J. Aarnikunnas \& A. Palva (2003). Probiotic and milk technological properties of Lactobacillus brevis. International Journal of Food Microbiology, 83, 63-74.

Schultz, M.; C. Vektkamp; L. Dieleman; W. Grenther; P. Wyrick; S. Tonkonogy \& S. Sartor (2002). Lactobacillus plantarum 299V in the treatment and prevention of spontaneous colitis in interleukin-10deficient mice. Inflammatory Bowel Diseases, 8, 71-80.

Schwan, R. \& A. Wheals (2004). The microbiology of cocoa fermentation and its role in chocolate quality. Critical Reviews in Food Science and Nutrition, 44, 205-221.

Ström, K.; J. Sjorgen; A. Broberg \& J. Schnurer (2002). Lactobacillus plantarum MiLAB 393 produces the antifungal cyclic dipeptides cyclo (L-Phe-L-Pro) and cyclo (L-Phe-trans-4-OH-L-Pro) and 3-phenyllactic acid. Applied and Environmental Microbiology, 68, 4322-4327.

Sunoj, S.; C. Igathinathane \& R. Visvanathan (2016). Nondestructive determination of cocoa bean quality using FT-NIR spectroscopy. Computers and Electronics in Agriculture, 124, 234-242.

Syukur, S.; B. Bisping; Z. Noli \& E. Purwati (2013). Antimicrobial properties and lactase activities from selected probiotic Lactobacillus brevis associated with green cacao fermentation in West Sumatra, Indonesia. Journal of Probiotics and Health, 1, 4.

Thompson, S.S.; K.B. Miller; A. Lopez \& N. Camu (2013). Cocoa and coffee. p. 881-889. In: Food. Microbiology: Fundamentals and Frontiers (M.P. Doyle \& R.L. Beuchat, Eds.), $4^{\text {th }}$ edition, ASM Press, Washington DC.

Tortoló, C.K. \& G.A. Bell (2015). Producción de proteínas recombinantes en Bacillus megaterium: estado del arte ICIDCA. Sobre los Derivados de la Caña de Azúcar, 49, 22-26.

Wullt, M.; M.L. Hagslatt \& I. Odenhoit (2003). Lactobacillus plantarum 299v for the treatment of recurrent Clostridium difficile-associated diarrhoea: a double-blind, placebo-, controlled trial. Scandinavian Journal of Infectious Diseases, 35, 365-367.

$$
* * 0 * *
$$

